\title{
Nuclear energy in Latin America in the face of economic and environmental challenges
}

\author{
Karla Elizabeth Segura-Millán Rivas ${ }^{1}$, Julieta Evangelina Sánchez Cano ${ }^{2} *$ \\ ${ }^{1}$ Universidad Juárez del Estado de Durango, Fanny Anitúa w/n, Los Ángeles, P.C. 34000, Durango, Durango, \\ 2* Corresponding author. Universidad Juárez del Estado de Durango, Fanny Anitúa w/n, Los Ángeles, P.C. \\ 34000, Durango, Durango, Mexico, Member of the National System of Researchers, CONACYT.
}

\begin{abstract}
:
The use of nuclear energy has many economic, social and environmental implications due, on the one hand, to the uses to produce usable energy for industries and other sectors, and on the other hand, to the uses for war purposes. Some minor and major accidents related to waste management, mishandling of equipment and natural disasters have created lasting impacts in the areas affected and their surroundings. In Latin America, there are six nuclear reactors distributed in Mexico, Argentina and Brazil, and other smaller units that operate with nuclear energy. Argentina and Brazil have future plans to expand their operations in their nuclear plants. The implications of the goals of these nations must be considered, in a rapidly changing world in which political, economic and environmental instability increase. The challenges of climate change and the prevalent risks of other unexpected natural phenomena should be considered, as potentially elevated costs to the human health and the environment, if these phenomena have a negative impact over nuclear reactors.
\end{abstract}

Keywords: Latin America, nuclear energy, climate change, nuclear accidents.

\section{Introduction}

In Latin America, the use of nuclear energy has been limited to industrial and research purposes in several countries. This region is considered to have the cleanest energetic matrix worldwide. The five main economies produce $80 \%$ of the energy within this region. However, the numbers change when Brazil is excluded from the scene, due to the fact that Latin America produces $52.4 \%$ of renewable energies, and without the presence of this country the percentage drops to $38.2 \%$. With Brazil, the group of countries bases $45.5 \%$ of their production of energy on fossil fuels, but without Brazil the percentage rises to $60 \%$. Specifically, nuclear energy constitutes $2.1 \%$ of the total production of energy in the region, and without Brazil the percentage drops to only $1.8 \%$ [1]. Only Argentina, Mexico and Brazil have nuclear reactors. In Argentina there are three active nuclear reactors (ATUCHA 1, ATUCHA 2 and EMBALSE), one under construction phase (CAREM 25) and one in phase of negotiations
(ATUCHA 3), which gives this country the status of being in process of expanding its operations in these nuclear reactors. Brazil counts with two active reactors (ANGRA 1 and ANGRA 2) while a third reactor (ANGRA 3) is under construction phase. With the recent changes in administration, Brazil in particular is undergoing plans to build, if possible, up to eight new reactors. Mexico instead, counts with two active reactors (CENTRAL 1 and CENTRAL 2 in Laguna Verde Nuclear Plant) located in the same nuclear plant. Currently, this country does not have further plans to expand operations by building new reactors. Argentina and Brazil are considering the expansion of their power reactors as nuclear energy is seen as an alternative to the production and use of other nonrenewable energy sources that are highly contaminant. Recently, Bolivia began a project with the assistance of Russia to build a nuclear reactor for research purposes which would be complete during the second half of 2019. Russia will be in charge of providing the nuclear fuel and 
building the nuclear plant [2]. In the other Latin American countries who are members of the Regional Cooperation Agreement for the Promotion of Nuclear Science and Technology in Latin America and the Caribbean, the use of nuclear energy is extensive, covering areas like human health, energy, food security, environment, industry and radiological security. [3]

Diverse risks exist with the use of nuclear energy, especially when nuclear plants are built and maintained. One of the problems arising from the handling of nuclear waste is the need to isolate them within deep geological repositories which pose great economic costs and further environmental problems on the long run, as these wastes take millions of years to degrade. [4] Some of the major risks of nuclear reactor management include serious inherent safety flaws, accidents in light-water reactors that could lead to very serious radioactive releases affecting millions; high costs of new reactor lines creating uncertain outcomes, safety problems arising from extending the lifetime of reactors, pressures from markets that promote practices that accelerate ageing and decrease safety margins, and possibility of active cooling failing [5]. Even if nuclear waste and the management of nuclear reactors is the adequate, following strict rules and protocols, certain phenomena associated to climate change and movement of tectonic plates can cause damages to the nuclear centrals. Extreme events that cause floods and draughts can affect diverse functioning mechanisms in reactors, increasing the potential for accidents [5].

Indirect effects stemming from the production and use of nuclear energy include pollution and degradation of the environment associated to mining activity to extract uranium. Plutonium, on the other hand, is produced artificially by nuclear fission processes. The cost of producing electricity by the means of nuclear energy is the most expensive and is considered unsustainable. [6]

Morales [7] mentions that globally there have been ten major accidents in nuclear reactors in five countries for multiple reasons. Five of these incidents took place in Japan, between 1997 and 2011. The other accidents took place in the United
Kingdom (1957), Soviet Union (1958), United States (1979), Ukraine (1986), and France (1999). Sato and Lyamzina [8] also point out to an accident in the facility RA-2 in Argentina in 1983 and another one in Brazil in 1987. Of these accidents, three have caused major environmental devastations and severe health problems. Moreover, Morales [7] details that the first two accidents that occurred in the United States and Ukraine were mainly caused by human errors, both in the design of the reactors and errors during the handling of the equipment. In the case of Japan, particularly in Fukushima, the disaster was caused by a 9.0 magnitude earthquake followed by a tsunami. The impact of the tsunami was the cause of the failures, being that the water touched the seawater pumps and reached the $10 \mathrm{~m}$ ground level, flooding the buildings and dampening the motors and the electrical equipment. [8] The end result is ecological damage, elevated costs from residual isolation, soil and water pollution, uninhabitable areas, health damage including psychological damage [9].

It is of utmost importance to evaluate on the long and medium run the advantages and disadvantages of the uses of nuclear energy for industrial purposes. The use of nuclear energy for war purposes must be avoided at all costs. Latin American countries do not want to be left behind in their own sustainable development goals. However, these countries will face the challenges of climate change and all the risks that it entails, including the elevated costs that arise as consequence of the effect of atypical natural disasters. The costs of flaws in the design of nuclear reactors, inadequate management of equipment and external factors that damage the functioning of reactors can be too elevated in terms of human health and the environmental impacts.

For such reasons mentioned above, within the context of the achievement of the Development Millennium Goals, it is of special concern the supply, availability, and economic and environmental acceptance of energy. Given the limited availability of oil-based sources, other sources of energy, including nuclear energy make up the spectrum of choices for each country. [10] 


\section{Development and limited uses of nuclear energy in Latin America}

During the decade of the 50's, after the events that took place in Hiroshima and Nagasaki during the World War II, several countries gathered to prevent the proliferation of nuclear weapons, create alliances and regulate the uses of nuclear energy for industrial, medical and research purposes.

After the introduction of the program Atoms for Peace in 1953, the International Atomic Energy Agency (IAEA) is founded in 1957, as a means for the United States to be able to exert greater control over the ways in which the rest of the countries would use nuclear energy [11]. United States in particular promotes the uses of nuclear energy in the Latin American region with the limitation that forbids the uses for war purposes. Since then, Brazil headed the nuclear energy industry, followed by Argentina and then Mexico, being that they are the only countries within the region that are capable of obtaining technologies to build nuclear reactors. Even when other countries did not have, and still do not have nuclear reactors, they joined these series of treaties. One of these treaties is the Non-Proliferation Treaty, created in 1968 in which most countries worldwide joined, including the Latin American countries.

Brazil and Germany signed an agreement in 1975 that stated that, with the support of the latter, a nuclear plant could be built, however, due to pressures with the United States, the Germans did not build the plant as was originally agreed. Finally, Brazil obtains the plant ANGRA1 from Westinghouse and planned to obtain eight additional reactors, but these plans were not carried out [12]. Subsequently, the agreement between Germany and Brazil allowed for the reactor ANGRA2 to be built and for the first planning stages for the construction of ANGRA3 to take place [13].

Argentina creates in 1950 the National Atomic Energy Commission followed by the beginning of necessary studies in 1964 to build the first unit construction known as ATUCHA 1. Argentina and Germany sign an agreement for the construction of ATUCHA 1. In 1974, when ATUCHA1 began operations, the construction of EMBALSE was initiated and was connected to the grid in 1984. Meanwhile, the construction of ATUCHA2 began in 1981 but was completed in 2006 and connected to the grid in 2015. Finally, the first stages of design and construction for a low power nuclear power plant known as CAREM began [14].

The use of nuclear power to generate electricity in Mexico begins with the bidding for the construction of a nuclear plant with two reactors during the 1960's. By 1976 the construction of Laguna Verde began and both reactors began operations in 1990 and 1995 respectively [15].

Following the guidelines of IAEA and Atoms for Peace, Colombia and Chile already worked with radioisotopes for medical and industrial purposes, even when they had not developed the technologies to build nuclear reactors, which allowed them to become members of this group of countries involved in these initiatives [11]. Another aspect that would be regulated was the creation of banks for the enrichment of uranium. United States, Russia, and countries of the European Union shaped the initiative. Through these banks, the production and uses of enriched uranium are offered to countries who do not possess the capacity to produce it in limited amounts [16]. This particular group of countries became known as the Nuclear Suppliers Group, or London Club, meeting for the first time in 1975 and officially created in 1978. Among the participant countries are Argentina and Brazil [17].

The management of nuclear energy in Argentina and Brazil has gone through a process of transformation. Since 1990, the energetic sector in Brazil was deregulated and privatized, reaching up to $80 \%$ of companies owned by the private sector by 2016 [13]. Meanwhile, in Argentina, a decline in the nuclear industry took place in the 80 's. In 2003, when Nestor Kirchner became president, the 
nuclear industry proliferated once more and conformed an important strategy to diversify the energetic matrix. The nuclear capacity of Argentina culminated in this country being among the few worldwide to produce and export nuclear technologies [16]. Among the most recent proceedings, Argentina became a member of the Nuclear Energy Agency in 2017 [14].

In 1962, Brazil proposed that the Latin American region would become a nuclear-free zone, but such proposal was originally not supported. However, in 1964, the Mexican government created a Permanent Preparatory Commission for the Denuclearization of Latin America in order to persuade the other countries to join. Finally, in 1967, most countries signed the Treaty for the Prohibition of Nuclear Weapons in Latin America and the Caribbean, also known as the Tlatelolco Treaty [11].

During the supervision processes and the incorporation of countries to these treaties and agreements, the guidelines to the uses of nuclear energy were established. Among these uses for medical purposes is the application of radioisotopes in the area of radiology and for research purposes in Latin America.

It was foreseen that a nuclear plant would be built in Ecuador, however, factors like the accident in Fukushima, the more viable option to build hydroelectric plants and changes within the administration within the regulating institutions in charge of nuclear energy uses froze the project [18].

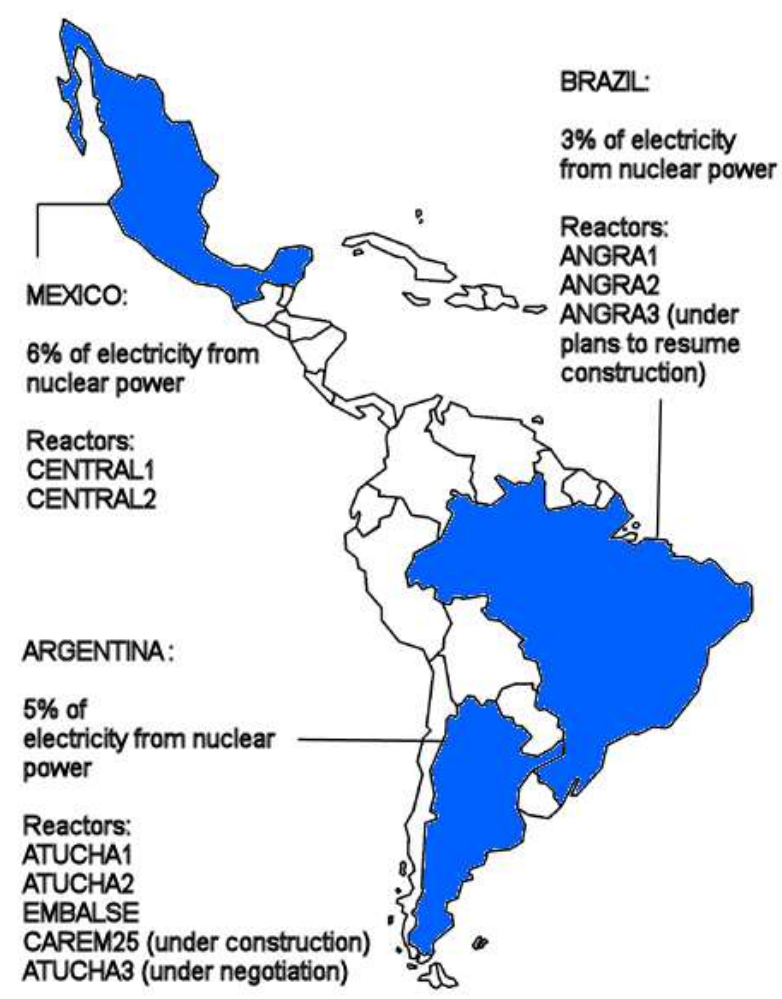

Figure 1. Distribution of nuclear reactors in Latin America and proportion of electricity produced from nuclear power. Source: self-elaborated using data from World Nuclear Association [19].

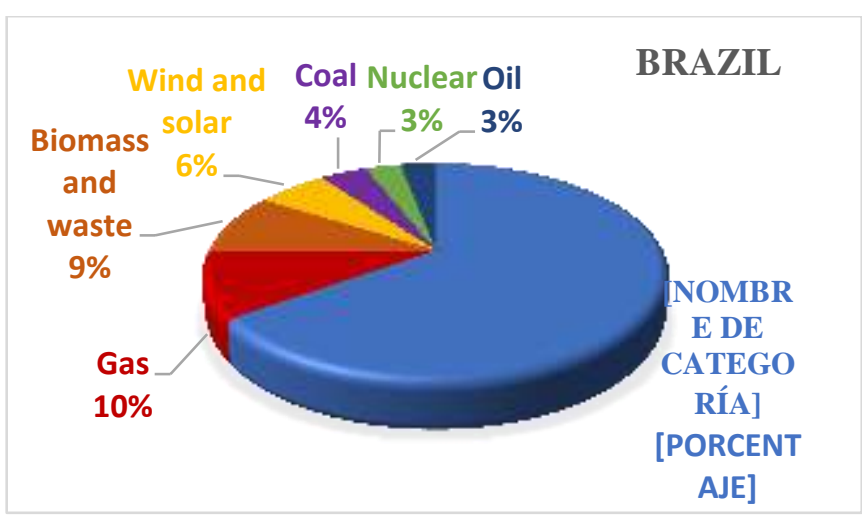

Figure 2. Proportions of energy sources in Brazil. Selfelaborated using data from Nuclear Energy Net [20]. 


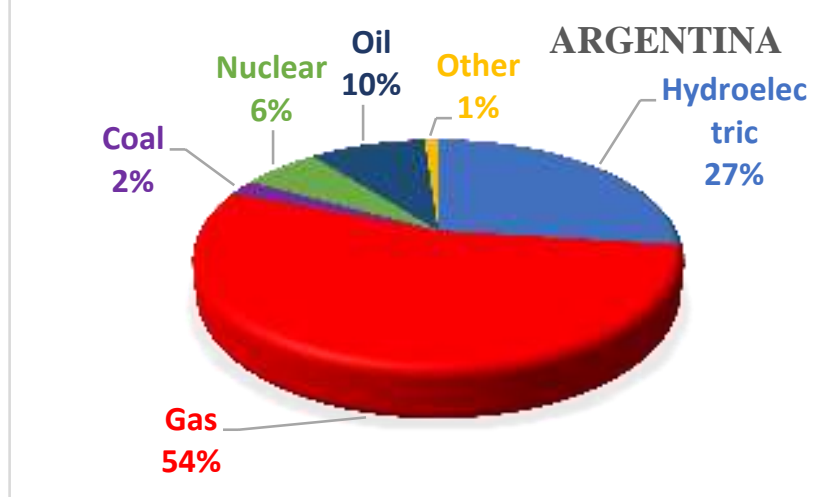

Figure 3. Proportions of energy sources in Argentina. Selfelaborated using data from Nuclear Energy Net [20].

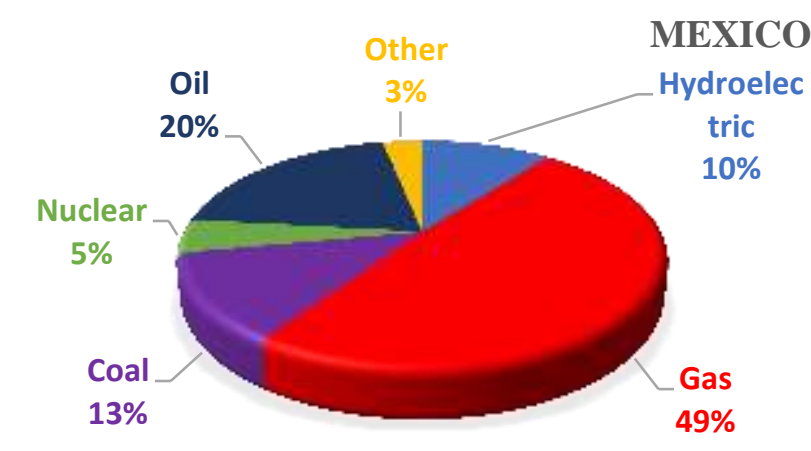

Figure 4. Proportions of energy sources in Mexico. Selfelaborated using data from Nuclear Energy Net [20].

\section{Economic and environmental costs of nuclear energy}

Nuclear energy is the most expensive of all forms of energy production, not only for the cost of building nuclear reactors, production and maintenance costs, but also for the costs of waste management, insurance, dismantling of the plants and transportation [6]. Even worse is the inclusion of the possible costs that arise from accidents and disasters caused by events such as the earthquake and tsunami in Japan in 2011. Such costs include the opportunity costs of not being able to use the contaminated areas destined to agricultural and forestry activities, fish farming, among others, which evidently affect other sectors of economic activity. Additionally, the costs on human health and relevant losses in flora and fauna would be included [21].

Diverse sources of radiation that artificially release to the environment this form of energy are identified. Osores [21] mentions that these sources stem from nuclear tests, nuclear reactors and radioactive residuals, radiologic accidents, uranium mining, radon and NORM materials. In the case of nuclear tests, the aim is in some cases to create boreholes, build canals and extract oil and gas. Both releases on the atmosphere and soil bring extensive consequences in the form of acid rainfall, radioactivity in the air and even in food.

In Latin America, particularly in the countries that have obtained technology to build nuclear reactors, the environmental cost of their functioning and the inadequate management of installations and waste have become evident. In Mexico, at least two incidents have taken place within the plant Laguna Verde, along with evidence of health problems in inhabitants of nearby areas where the reactors are located. In the year 2017, two individuals working within the plant showed evidence of internal contamination; in 2006 a problem that froze the control console without the option of turning off reactor Central 2 had already occurred, and another problem detected involved the irregular management of toxic waste [22].

In Argentina, between 1987 and 1988 two incidents of lesser magnitude took place in reactor ATUCHA I. A spillover of heavy water and subsequently a problem with the cooling channels, which caused that in diverse occasions the power supply would be cut off. This caused social and even political pressures, without counting high costs derived from inspections, repairs and power cuts [23].

Anjos et al. [24] conducted a study in 2001 in a contaminated area with radioactive Cesium in Goiania, Brazil. In 1897, a group of people intentionally damaged a capsule of ${ }^{137} \mathrm{Cs}$ in an abandoned radiotherapy unit out of curiosity caused by the luminescence of the source. Four people died after the incident and around 250 people were contaminated. The results of the study showed that 12 years after the incident, the area was still contaminated with higher levels of radiation from Cesium than what was aimed after decontamination efforts. 
In Brazil and Argentina, mining of uranium has been practiced since the 60's and 70's. However, the environmental costs not only involve the typical contamination that stems from conventional mining activity, but also the high rate of gamma emission, radon gas released to the atmosphere, high concentration of radionuclides and probability of contamination of groundwater systems [21].

\section{Climate change and natural disasters in Latin America}

Mexico's policy regarding climate change includes the compromise to help reduce greenhouse gas emissions. Clean energy goals include bringing down carbon intensity of the economy by more than half and supporting the proliferation of renewable energies [15].

Currently, the present administration is investing in thermoelectric plants and the strengthening of a deteriorated oil sector, but the expansion plans for the energetic sector does not contemplate investments in new reactors. In fact, the current president Andrés Manuel López Obrador rejected any form of investment in this sector [25].

One of the main risks associated to the location of Laguna Verde in Veracruz is the seismic activity present in that area, which extends to the coasts of the Gulf of México. Near the nuclear plant, small communities are located [26]. Sara et al. [27] present some examples of conspicuous seismic activity in the state of Veracruz, mostly in the central and southern portion of the state. Four of these events were of magnitude above $4 \mathrm{Mw}$.

Another risk pertains the closeness of the nuclear plant to the Gulf of Mexico, where the coast is prone to be hit by hurricanes. With climate change, the magnitude of hurricanes hitting the coasts is more uncertain. Tovar et al. [28] illustrate the possible effects of climate change in an area of Veracruz near the coast that would be affected if the sea level rises as high as 5 meters. The economic and social losses of such scenario would have an important impact nationally. Even worse, if Laguna Verde would be considered within the possible scenarios of flooding and winds damaging the installations, the radiation would affect the ecosystems, the land designated for agricultural activities and other economic activities and the health of thousands of people.

In Argentina, Atucha I is located at the bank of the Paraná river, which flows into the Atlantic Ocean, while a smaller nucleo-electric plant is located near Buenos Aires, almost at the edge of the coast. Climate variability in Argentina caused by climate change includes an increase in the frequency of extreme rainfall, rise in the water levels of rivers and increase in sea levels. These increases bring as consequence rises in the water level of the Paraná river, among others [29], which could represent a risk for the nuclear reactors.

The current Brazilian administration plans to conclude the construction of the ANGRA 3 reactor and up to eight more reactors as stated in The National Energy Plan 2030 [30]. The future of Brazil in relationship to the protection of natural resources and investment in renewable energies seems dull, as Jair Bolsonaro has recently declared that environmental policy "suffocates" the economy, as his belief, and that of many of the members of his cabinet, is that economic development and environmental matters are opposing [31].

Brazil is not exempt of experiencing extreme weather events and other natural occurrences that can represent a risk in areas where nuclear reactors are located. Corrêa [32] states that, where Angra 3 is being constructed, the land experiences massive landslides and frequent flooding on a regular basis, leading to power outages, sweeping away and burying buildings, bridges, roads and other infrastructure. In cases of emergency, evacuation of the plant and the population nearby would be hard to achieve.

\section{Conclusion}

Where nuclear reactors are located, no country is exempt from facing a diversity of risks, some 
which can be caused by natural disasters. As the effects of climate change increase, such risks of accidents in nuclear reactors increase. Argentina, Brazil and Mexico have faced a series of incidents in their nuclear reactors and other installations where some form of nuclear material has been used. From such experiences and from the experiences of other countries that have faced major accidents, the current and future administrations must not turn away from precatory measures regarding the uses of nuclear energy. More so, in the case of Brazil, as the current administration has plans of heavy investments in several reactors during the coming years.

\section{References:}

[1] Balza L., Espinasa R. and Serebrisky T. Lights On? Energy needs in Latin America and the Caribbean to 2040. Inter-American Development Bank. Felipe Herrera Library. 2016.

[2] Rosatom América Latina. ABC Nuclear: 74 preguntas y respuestas sobre las tecnologías nucleares, Rosatom, Agencia Boliviana de Energía Nuclear, Primera edición, Marzo 2018, La Paz, Bolivia. http://www.aben.gob.bo/es/files/ABC_nucl ear.pdf [Accessed on: February 17, 2019].

[3] International Atomic Energy Agency, ARCAL Regional strategic profile for Latin America and the Caribbean, Vienna, Austria, 2015. Obtained from: https://www-

pub.iaea.org/MTCD/Publications/PDF/TE1763_E_web.pdf [Accessed on: February 17, 2019].

[4] Storm Van Leeuwen, J. Health risks of nuclear power. Ceedata energy analysis, Briefing 79. 2010. Obtained from: http://www.nuclearpolicy.info/docs/briefin gs/A194_(NB79)_NFLA_Briefing_79_Rad iation_health_risks.pdf [Accessed on: February 13, 2019].

[5] Hirsch H., Becker O., Schneider M., Frogatt A. Nuclear reactor hazards: ongoing dangers of operating nuclear technology in the $21^{\text {st }}$ century. Estudos Avancados, 21:59, 253-257. 2007.

[6] Buján S. Energía nuclear, una historia de engaños, ocultamiento y abandono. BIOS Argentina. 2016. Obtained from: http://www.ifcc.org/media/433203/Energ\% C3\%ADa_Nuclear_BIOS.pdf [Accessed on: February 10, 2019].

[7] Morales Pedraza, M. World major nuclear accidents and their negative impact in the environment, human health and public opinion, International Journal of Energy, Environment and Economics, 21:2, 1-23. 2013

[8] Mizokami S. and Kumagai Y. Event sequence of the Fukushima Daiichi accident. In: Ahn J., Carson C., Jensen M., Juraku K., Nagasaki S. and Tanaka S. (Ed) Reflections on the Fukushima Daiichi nuclear accident: Toward social-scientific literacy and engineering resilience. Springer Open. New York Dordrecht London. 2015.

[9] Sato A. and Lyamzina Y. Diversity of concerns in recovery after a nuclear accident: a perspective from Fukushima. International Journal of Environmental Research and Public Health. 15:2, 350. 2018

[10] Filipovic, M., Jovanović Popović, D., Nešić S. The role of nuclear energy for sustainable development goals. Conference paper - Security concepts and policies new generation of risks and threats, Ohrid, Republic of Macedonia. 2017. Obtained from:

https://www.researchgate.net/publication/3 14281780_The_role_of_nuclear_energy_fo r_sustainable_development_goals [Accessed on: February 21, 2019].

[11] Mateos G. and Suárez-Díaz E. Atoms for Peace in Latin America. 2016. Oxford research encyclopedia of Latin American history. Oxford University Press. USA. 2019. Obtained from: http://oxfordre.com/latinamericanhistory/vi ew/10.1093/acrefore/9780199366439.001. 0001/acrefore-9780199366439-e- 
317\#ref_acrefore-9780199366439-e-317note-6 [Accessed on: February 22, 2019].

[12] Kinjo H.¿Por qué América Latina no tiene bomba nuclear? Revista Diners. No. 94, 1978. 2018. Obtained from: https://revistadiners.com.co/archivo/55540 _america-latina-no-bomba-nuclear/ [Accessed on: February 10, 2019].

[13] IAEA. Brazil. Country Nuclear Power Profiles. International Atomic Energy Agency. 2016. Obtained from: https://cnpp.iaea.org/countryprofiles/Brazil /Brazil.htm [Accessed on February 23, 2019].

[14] IAEA. Argentina. Country Nuclear Power Profiles. International Atomic Energy Agency. 2018. Obtained from: https://cnpp.iaea.org/countryprofiles/Argen tina/Argentina.htm [Accessed on: February 24, 2019].

[15] IAEA. Mexico. Country Nuclear Power Profiles. International Atomic Energy Agency. 2018. Obtained from: https://cnpp.iaea.org/countryprofiles/Mexic o/Mexico.htm [Accessed on: February 24, 2019].

[16] Colombo S., Guglielminotti C. and Nevia Vera M. El desarrollo nuclear de Argentina y el régimen de no proliferación. Perfiles latinoamericanos. 25:49, 119-139. 2017. Obtained from: http://www.scielo.org.mx/scielo.php?script =sci_arttext\&pid=S0188-

76532017000100119\&lng=es\&nrm=iso [Accessed on: February 26, 2019].

[17] Nuclear Threat Initiative. Nuclear Suppliers Group. Nuclear Threat Initiative: Building a safer world. Washington D.C. 2018. Obtained from: https://www.nti.org/learn/treaties-andregimes/nuclear-suppliers-group-nsg/ [Accessed on: February 26, 2019].

[18] Carrasco J. Situación actual del Ecuador en el uso y aplicaciones nucleares. International Youth Nuclear Congress: Delegation to Latin America. Argentina, Brazil. 2016. Obtained from: https://www.researchgate.net/publication/2 99423789_SITUACION_ACTUAL_DEL_
ECUADOR_EN_EL_USO_Y_APLICACI ONES_NUCLEARES [Accessed on: February 17, 2019].

[19] World Nuclear Association. Nuclear power in the world today, World Overview. 2019. Obtained from: http://www.worldnuclear.org/information-library/currentand-future-generation/nuclear-power-inthe-world-today.aspx. [Accessed on: February 22, 2019].

[20] Nuclear Energy Team. Situation in the World. Nuclear Energy. 2018. Obtained from: https://nuclear-energy.net/situation [Accessed on: February 16, 2019].

[21] Osores J. Environmental radioactive pollution in neotropic. Biologist. 6:2, 155165. 2008.

[22] Salas Mar B. La energía nuclear como alternativa energética. Firsth North-South Conference Degrowth-Descrecimiento. Mexico city. 2018. Obtained from: https://degrowth.descrecimiento.org/docum entos/in-extenso/00483.pdf [Accessed on: March 5, 2019].

[23] Almagro J., Perazzo R. and Sidelnik J. Crónica de una reparación (im)posible: el incidente de 1988 de la C.N. de Atucha I. 1st edition. Ciudad Autónoma de Buenos Aires. Asociación Argentina para el progreso de las ciencias. 2017.

[24] Anjos R., Umisedo N., Facure A., Yoshimura E., Gomes P. and Okuno E. Goiania: 12 years after the Cs-137 radiological accident. Radiation Protection Dosimetry. 101:1-4, 201-204. 2002.

[25] Zarco J. AMLO: Primeros trazos de energía. PV Magazine. Edición México. 2018. Obtained from: https://www.pvmagazine-mexico.com/2018/07/02/amloprimeros-trazos-de-energia/ [Accessed on: March 20, 2019].

[26] Parra M. and Becerra O. La energía nuclear , ¿una opción de energía segura en México? Bioética y Derecho. Bioética Web. 2019. Obtained from: https://www.bioeticaweb.com/la-energia- 
nuclear-una-opcion-de-energia-segura-enmexico-2/ [Accessed on: March 6, 2019].

[27] Franco S., Canet C., Iglesias A. and Valdés-González C. Seismic activity in the Gulf of Mexico. A preliminary analysis. Boletín de la Sociedad Geológica Mexicana. 65:3, 447-455. 2013.

[28] Tovar R., Vázquez F., and Vázquez S. Impacts and adaptation to climate change in Veracruz. Rumbos TS. 10:12, 119-129. 2015.

[29] Menéndez A. Efectos hidrológicos del cambio climático en Argentina. Desafíos del cambio climático y global en Argentina. Primeras jornadas interdisciplinarias de la Universidad de Buenos Aires sobre el cambio climático y global. In: Besalú A. (Ed). Universidad de Buenos Aires, Argentina. 2007.

[30] Bandeira R. Government Jair Bolsonaro plans to build up to eight nuclear power plants. Suno News. 2019. Obtained from: https://www.sunoresearch.com.br\%2Fnotic ias\%2Fgoverno-bolsonaro-construirusinasnucleares\%2F\&usg=AOvVaw11Aiu69o40 DtteniB-tgbG [Accessed on: March 20, 2019].

[31] Viscidi L. and Graham N. Brazil was a global leader on climate change. Now it's a threat. Argument. Foreign Policy. 2019. Obtained from: https://foreignpolicy.com/2019/01/04/brazi l-was-a-global-leader-on-climate-changenow-its-a-threat/ [Accessed on: March 21, 2019].

[32] Corrêa F. Is a nuclear catastrophe potentially possible in Angra 3 plant and what are possible scenarios for this, based on the weakness of the planned design and the lessons learnt from Fukushima? Greenpeace. 2012. Obtained from: http://br.boell.org/sites/default/files/downlo ads/Estudo_Francisco_Correa_Angra_3.pd f [Accessed on: March 21, 2019]. 